Teknomekanik

Vol.1, No.1, June 2018, pp. 1 5

E-ISSN: 2621 - 8720 P-ISSN: 2621 - 9980

\title{
Analysis of Tensile Strength the Fiber Bagasse Particles Board with Resin Adhesives
}

\author{
Hendri Nurdin, Yolli Fernanda and Meisuri Handayani \\ Jurusan Teknik Mesin, Fakultas Teknik, Universitas Negeri Padang, Indonesia
}

\begin{tabular}{|c|c|}
\hline Article Info & ABSTRACT \\
\hline Article history: & \multirow{14}{*}{$\begin{array}{l}\text { Development of the material be in the form of Particles it is possible to do so } \\
\text { it can be an alternative to wood. Particle board is an engineered material } \\
\text { that utilizes waste bagasse after sugar cane extraction process as an } \\
\text { amplifier and as an adhesive used resin. Particle boards that have been } \\
\text { produced, generally using wood powder, while the use of wood has been } \\
\text { limited and diminished due to difficulty getting it. So the need for } \\
\text { development in engineering the main material particle board in the form of } \\
\text { wood powder and replace it with waste bagasse. The particle board } \\
\text { manufacturing process is carried out by forging (compacting) between the } \\
\text { mixture of sugarcane pulp particles and the BQTN } 157 \text { Resin adhesive. } \\
\text { Percentage of mixed usage 50: 50 based on the fraction of weight and } \\
\text { volume. In obtaining the mechanical properties carried out by tensile testing. } \\
\text { From this research, the average particle pull strength is } 1.81 \text { MPa, strain } \\
13,52 \% \text { and elasticity } 0,013 \text { GPa. In obtaining particle board as an } \\
\text { engineering material that has good ability influenced many things such as } \\
\text { particle (mesh) raw material, adhesive use, mixed composition, the process } \\
\text { of forging. From the characteristics of the test results obtained so that the } \\
\text { particle board of the bagasse with resin adhesive is very possible to replace } \\
\text { the type of particle board made from raw wood powder. }\end{array}$} \\
\hline Received Jan 01 ${ }^{\text {th }}, 2018$ & \\
\hline Revised March $01^{\text {th }}, 2018$ & \\
\hline Accepted May $24^{\text {th }}, 2018$ & \\
\hline Keywords: & \\
\hline Sugarcane baggage & \\
\hline Resin BQTN 157 & \\
\hline Particleboard & \\
\hline Tensile strength & \\
\hline & \\
\hline & \\
\hline & \\
\hline & \\
\hline & \\
\hline
\end{tabular}

Corresponding Author:

Hendri Nurdin,

Jurusan Teknik Mesin, Fakultas Teknik, Universitas Negeri Padang

Jln. Prof. Dr Hamka Air Tawar, Padang (25131), Sumatera Barat, Indonesia

Email: hens2tm@yahoo.com

\section{INTRODUCTION}

The development of the age that is accompanied by the rapid development of science and technology today creates an era of globalization that demands all to participate in it. So that human resources must master science and technology and ability to apply it in life. The technology of the material field is growing rapidly nowadays along with the material needs for certain characteristics [1]. Today's rapid technology is particle board. Particleboard which is an artificial board made of wood chips (wood powder) wood processing industry with the help of synthetic adhesive then processed by forging so it has properties such as wood. Meanwhile, the serious problem faced by the wood processing industry in Indonesia today is the shortage of wood raw materials that will be in though (production). This is reflected in the declining value of the forestry sector from 6\% in 1997 to only about $1 \%$ in 2004 [2]. Furthermore, because the speed of timber utilization is not balanced with the speed of new stand development. meanwhile, the need for wood for the production of building materials, coatings, particle board, and other purposes continues to increase as the population grows and increases.

The need for timber use in the community is very diverse, such as replacing wood damaged, weathered or eaten by termites. In addition, the need for wood as a household furniture is also a lot, especially particle board as furniture. In addition, the need for wood as a household furniture is also a lot, especially particle board as furniture. Such as particle board made of wood powder, also adds the use of wood as a processing material. With the increasing need for wood, the wood that will be used as processing materials in the industry decreases, therefore the material is replaced with other materials that reduce the need for wood. Particleboard which is a material that can be produced from raw materials such as wood is particle board from lignocellulosic materials obtained from plants and given adhesive and then pressed so that it has

Journal homepage: http://teknomekanik.ppj.unp.ac.id

DOI: https://doi.org/10.24036/tm.v1il.172 
properties such as wood. Therefore it is necessary to look for the alternative material of wood powder substitute which characteristic same as wood for particle board processing.

One of the plants that contain lignocellulosic materials that cane crops that have the potential to be used as engineering materials in the form of particle board. Sugar mill as a place of sugar cane processing into sugar that produces waste bagasse as remaining processing. Generally, sugar factories in Indonesia also use sugarcane as a fuel for the factory, after the bagasse is drying. But not entirely utilized for fuel, there are still some that become waste or waste is wasted. Especially in the community of sugarcane juice sellers, the rest of the sugarcane mill is sugar cane bag also becomes waste or waste that is not utilized anymore. Can be known usability bagasse used as fuel, as a raw material in the paper industry, particleboard, fibreboard, and others. With the abundance of waste bagasse that is not utilized and become waste in the community is possible to do further processing. One effort that can be made to increase the economic value of bagasse waste is by utilizing waste technology as particleboard material. Particle boards with bagasse feeders may use resin adhesives, urea formaldehyde adhesives and artificial adhesives typically used for furniture, and there are also melamine resin adhesives used for high-humidity air conditions, whereas waterproof particle board as home walls is used phenol formaldehyde.

The use of sugarcane in the particle board industry has been done by Krisna Margaretta, with the manufacture of particle board made from raw sugar cane adhesive urea formaldehyde. It can be known that urea formaldehyde adhesive is very difficult to obtain, therefore in this research making particleboard made from raw bagasse is used resin adhesive type which is easy to get with cheap [3]. According to [4], the ratio of the volume fraction contained by the composite board will affect its strength. The purpose of this research is to obtain the strength value of particleboard made from resin adhesive bagasse and to know the procedure of making particleboard made from resin sticker bagasse.

\section{METHOD}

The experiment is a type of experimental research, where the test results are obtained through direct experiments on specimens. The research data was obtained through the result of tensile test of the specimen and analyzed according to a study from research. The object of research to be investigated is particle board made to meet JIS A 5908-2003 standard [5] from the raw material of bagasse containing 2-4\% water content mixed with BQTN 157 resin adhesive where sample size $25 \mathrm{~cm}$ x $12,5 \mathrm{~cm}$ x $12 \mathrm{~mm}$.

The process of making particle board is to supply bagasse and resin adhesive and catalyst and then measured according to the variation of 50\% bagasse bag - 50\% resin. The supplied material is fed into a 25 $\mathrm{cm} \times 12.5 \mathrm{~cm} 12 \mathrm{~mm}$ thick printer then cold-pressing using a jack, after which it is heated into the oven at $1000 \mathrm{C}-1400 \mathrm{C}$ for 60 minutes. The hot sheets are removed from the printer and left for about 3 hours for hardening of the adhesive, then conditioning for a week to achieve a uniform water content distribution and releasing residual stresses in the board due to the forging.

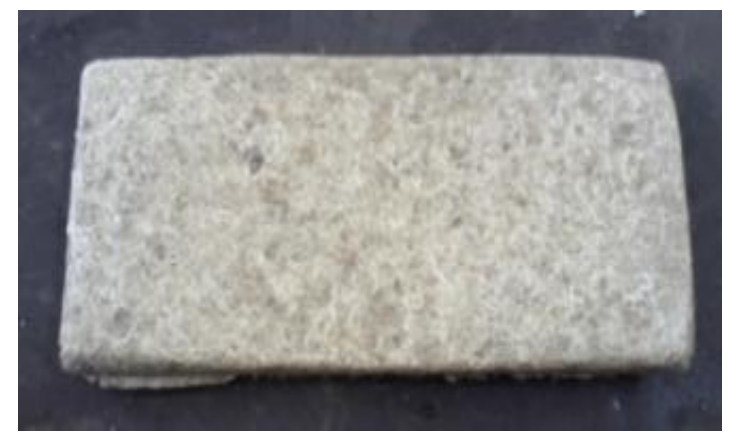

Figure 1 : Particleboard after printing

After the printing process is completed the cutting is done according to the size of the specimen with manual workmanship using a saw, the test specimen is formed accordingly (Figure 2) ASTM D638 M standard [6] tested using Tension Testing Machine. 


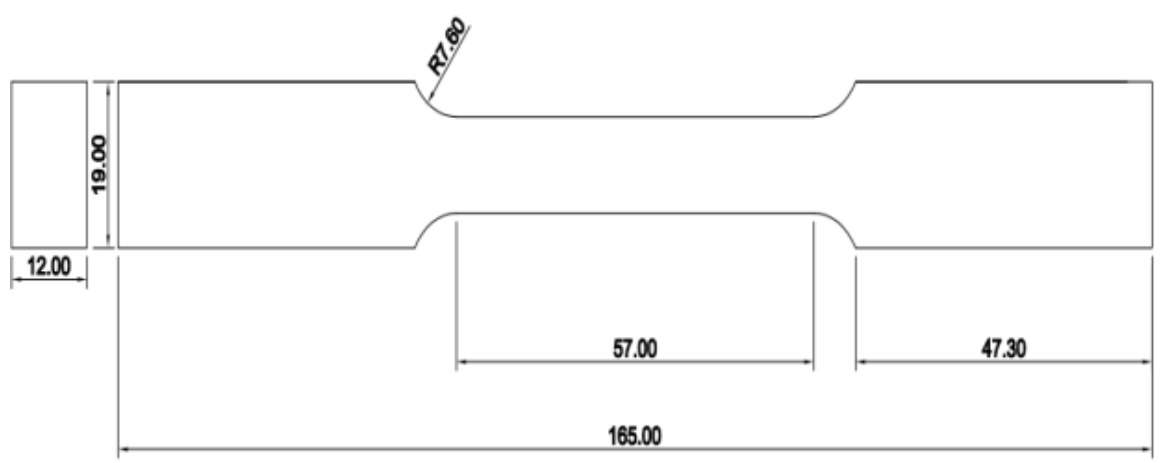

Figure 2 : The shape and dimensions of the test specimen

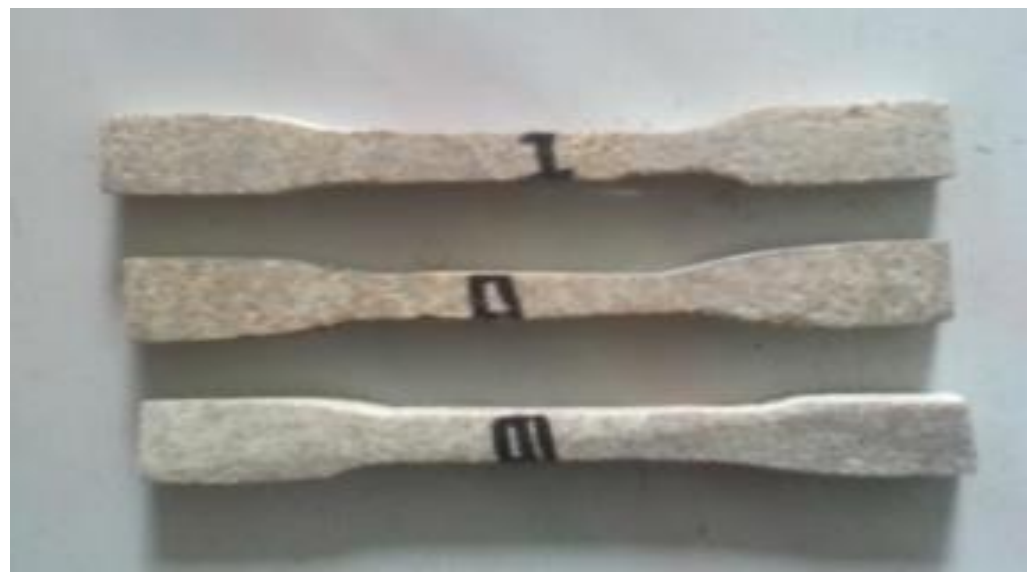

Figure 3 : Tensile test specimens

\section{RESULT}

Tensile testing which has been done by using Tension Testing Machine on all specimens of particle board of resin adhesive bagasse, obtained the result as shown in the following table:

Table 1. Results of Pull Voltage and Particle Length Increment

\begin{tabular}{|c|c|c|c|c|c|c|}
\hline \multicolumn{2}{|c|}{$\begin{array}{c}\text { Comparison of volume } \\
\text { fractions }\end{array}$} & \multirow{2}{*}{ Specimen } & \multirow{2}{*}{$\begin{array}{l}\text { Percentage of } \\
\text { length } \\
\text { increase }(\Delta \mathrm{L}) \\
(\%)\end{array}$} & \multirow{2}{*}{$\begin{array}{c}\text { Tensile } \\
\text { Voltage }(\sigma) \\
(\mathrm{MPa})\end{array}$} & \multirow{2}{*}{$\begin{array}{c}\text { Strain }(\varepsilon) \\
(\%)\end{array}$} & \multirow{2}{*}{$\begin{array}{c}\text { Modulus of } \\
\text { Elasticity (E) } \\
\quad(\mathrm{GPa})\end{array}$} \\
\hline $\operatorname{Resin}(\%)$ & $(\%)$ & & & & & \\
\hline \multirow{3}{*}{50} & \multirow{3}{*}{50} & I & 0,64 & 1,684 & 12,307 & 0,013 \\
\hline & & II & 1 & 2,972 & 23,356 & 0,012 \\
\hline & & III & 0,3 & 0,792 & 4,918 & 0,016 \\
\hline
\end{tabular}

In table 1 can be seen by comparison of particle board between specimen 1, specimen 2 and specimen 3 and shown by using the graph of stress and strain relationship and graph of stress relation with a modulus of elasticity. 


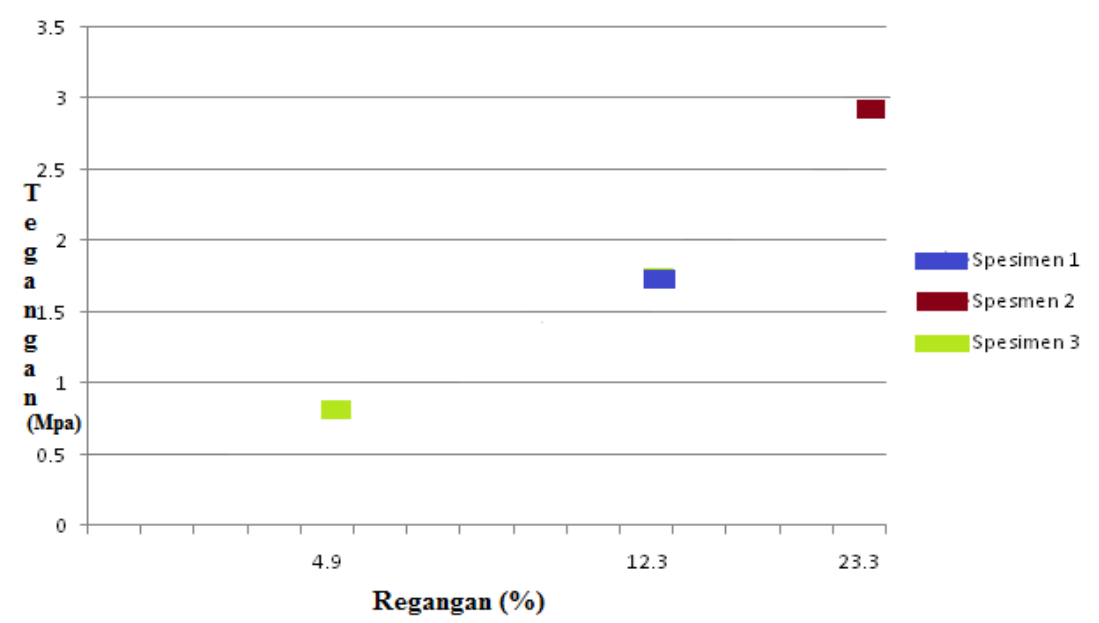

Figure 4 : Graph of stress relationship with strain

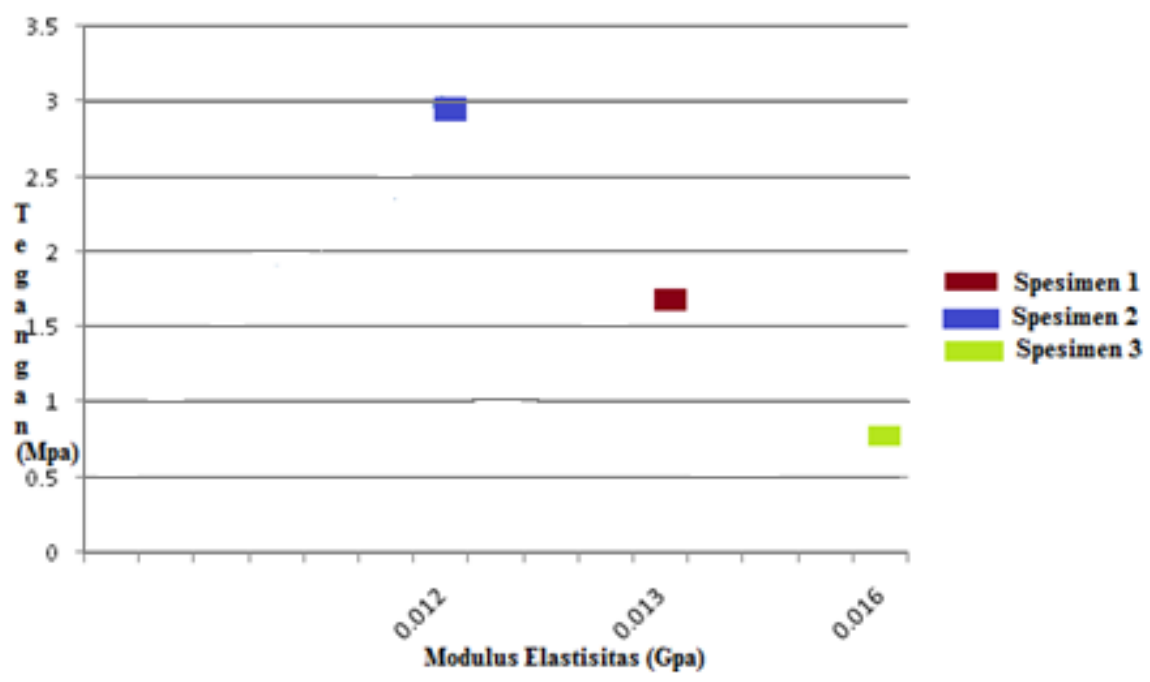

Figure 5 : Graph of the voltage relationship with the modulus of elasticity

From the graph of the stress related with strain can be seen that the higher the voltage that occurs the higher the strain and the lower the modulus of elasticity obtained because in Hooke Law theory there is a straight comparison between elasticity with stress and strain.

\section{DISCUSSION}

Based on this research can be explained that the value of tensile strength obtained from the results of a tensile test average of $1.81 \mathrm{MPa}$, with a strain of $13.52 \%$, and the modulus of elasticity $0.013 \mathrm{GPa}$. From this condition can be explained by the manufacture of particle board is generally produced is a medium density particle board for providing optimum results in terms of mechanical, adhesive use and other economic aspects. Analysis of tensile strength of the particle board made from resin-bonded bagasse by obtaining a value of stress that can be retained by the specimen to the maximum (in the fracture state) and obtaining the mean tensile strength value with the mathematical calculation of the test results, based on the opinion of Anusavice stating that tensile strength, shear strength, compressive strength and flexure strength are each measure of pressure required to break a material, the calculation of tensile strength can be calculated and analysed after the particle board is tested until it is broken.

The result of the tensile test can be explained that on the particle board the effect of adhesive elements should be more adhesive composition than the filler composition of bagasse. Because in principle the most decisive factor in the manufacture of particle board is the adhesive. In addition to the adhesive factor affecting the strength of the particle board, it also influences the factors of the forging process is one of the 
characteristics of particle board making, namely the primary processing through particle formation, the formation of the expanse and the forging which produces particle board.

\section{CONCLUSION}

Based on research and testing on particle board of standard raw bagasse by using resin adhesive obtained result which can be concluded of them can know the utilization of waste bagasse as the raw material making particle board mixed with a resin adhesive. The process of making particle board with compression system is done manually, then tested and get the average tensile strength value of $1.81 \mathrm{MPa}$, strain 13,52\% and elasticity 0,013 GPA. From the manufacture and test of the particle board, it can be stated that factors affecting the particle board strength include the raw material (mesh) particles, the use of the adhesive, the composition of the mixture, the process of forging. Utilization of bagasse waste in the manufacture of particle board as an alternative engineering material is very possible to replace wood powder as the main material of particle board so far so that furniture made from wood can also be replaced with the particle board made from bagasse. From the characteristics of the test results obtained so that the particle board of the bagasse with resin adhesive is very possible to replace the type of particle board made from raw wood powder.

\section{REFERENCE}

[1] Nabawi, R. A. Analisis Kekuatan Tarik Komposit Polimer Berpenguat Serat E-glass yang dibeikan Perlakuan Alkali (NaOH). Bachelor Thesis. Padang: Universitas Negeri Padang; 2012.

[2] Dinas Kehutanan Propinsi Jawa Tengah. Inventarisasi Industri Primer Hasil Hutan Kayu (IPHHK) Propinsi Jawa Tengah Tahun 2006. Semarang. 2006.

[3] Krisna Margaretta Pemanfaatan Ampas Tebu Sebagai Bahan Baku Dalam Pembuatan Papan Partikel. Skripsi; 2009.

[4] Nurdin, H. Pengaruh Penggunaan Jenis Serat Pada Komposit Polimer Terhadap Kekuatan Tarik. Zona Teknik. Vol. 3. No. 2. Hal. 143, 150; 2008.

[5] JIS A 5908. 2003. Particles Boards, Japanese Standard Association, Japan.

[6] Standard ASTM D638 M (ASTM, 2002) 